[Article]

\title{
氧化钯作为电位型传感器中敏感电极的工作机理
}

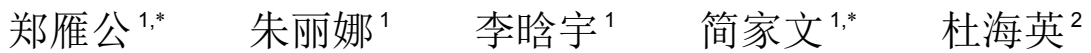 \\ ( '宁波大学信息科学与工程学院, 浙江宁波 $315000 ;{ }^{2}$ 大连民族大学机电工程学院, 辽宁大连 116600)
}

\begin{abstract}
摘要: 研究了基于氧化钯 $(\mathrm{PdO})$ 电极的电位型传感器的敏感特性, 并探讨了其敏感机理。首先, 利用 $\mathrm{Mg} 、 \mathrm{Ni}$ 和 $L a$ 元素对 $P d O$ 电极进行掺杂, 将掺杂后的 PdO 电极印刷在氧化铅电解质上, 制备成电位型传感器, 并对 一氧化碳 $(\mathrm{CO})$ 的敏感特性进行了测试。由于掺杂后的 $\mathrm{PdO}$ 电极表面缺陷增加, 这有利于对 $\mathrm{CO}$ 的吸附, 有效 地提高了传感器的灵敏度。其次, 为了探究敏感信号的来源, PdO 电极分别印刷在氧化铝和沸石基片上, 同 样测试了对 $\mathrm{CO}$ 的敏感特性。其中 $\mathrm{PdO}$ 电极与沸石所组成的电位型传感器对 $\mathrm{CO}$ 浓度可以产生阶梯型响应。 最后, 对传感器分别进行了电阻和阻抗谱的测量, 测量结果表明: 传感器的响应可以归因于电极和电解质之 间界面电位的变化。综合上述研究结果, 建立了电偶层模型来解释基于 PdO 电极的电位型传感器的工作机 理。
\end{abstract}

关键词: 氧化钯; 电位型传感器; 掺杂作用; 一氧化碳; 电解质

中图分类号: 0646

\section{Operating Mechanism of Palladium Oxide as a Potentiometric Sensing Electrode}

\author{
ZHENG Yan-Gong ${ }^{1, *}$ \\ ZHU Li-Na ${ }^{1}$ \\ LI Han-Yu ${ }^{1}$ \\ JIAN Jia-Wen ${ }^{1, *}$ \\ DU Hai-Ying ${ }^{2}$ \\ (' ${ }^{1}$ Faculty of Electrical Engineering and Computer Science, Ningbo University, Ningbo 315000, Zhejiang Province, P. R. China; \\ ${ }^{2}$ College of Mechanical and Electronic Engineering, Dalian Minzu University, Dalian 116600, Liaoning Province, P. R. China)
}

\begin{abstract}
This paper describes the sensing properties of a potentiometric sensor based on a palladium oxide (PdO) electrode. Our investigation of the sensing mechanism is also discussed. We studied carbon monoxide (CO) sensing performance of a $\mathrm{PdO}$ electrode doped with $\mathrm{Mg}, \mathrm{Ni}$, and $\mathrm{La}$, printed on zirconia. The results indicated that defects on the surface of $\mathrm{PdO}$, which allow adsorption of $\mathrm{CO}$, can effectively enhance the sensitivity of the sensors. To explore the source of the signal, a PdO-based electrode was printed on an alumina disc and a zeolite pellet for $\mathrm{CO}$ detection at $450{ }^{\circ} \mathrm{C}$. Notably the zeolite coupled with the PdO-based electrode to generate potentiometric responses to changes in $\mathrm{CO}$ concentration. According to the resistance and impedance measurements, the response to $\mathrm{CO}$ was ascribed to the changing interfacial potential between the $\mathrm{PdO}$ electrode and electrolyte. A model based on an electrochemical double layer between the $\mathrm{PdO}$ and electrolyte was determined to explain the behavior of the potentiometric sensor. It may be possible to harness these effects at PdO electrodes for the development of electrochemical sensors.
\end{abstract}

Key Words: Palladium oxide; Potentiometric sensor; Doping effect; Carbon monoxide; Electrolyte

Received: October 24, 2016; Revised: December 12, 2016; Published online: December 12, 2016.

${ }^{*}$ Corresponding authors. ZHENG Yan-Gong, Email: zhengyangong@nbu.edu.cn; Tel: +86-13216681910.

JIAN Jia-Wen, Email: jianjiawen@nbu.edu.cn; Tel: +86-13780047417.

The project was supported by the National Natural Science Foundation of China (61471210, 61501271, 51472126), Natural Science Foundation of Ningbo Municipality, China (2015A610108), and K. C. Wong Magna Fund in Ningbo University, China.

国家自然科学基金(61471210, 61501271, 51472126), 宁波市自然科学基金(2015A610108)及宁波大学王宽诚幸福基金资助项目

(c) Editorial office of Acta Physico-Chimica Sinica 


\section{Introduction}

For nearly a century, solid-state potentiometric sensors that employ oxide electrodes have been extensively studied and applied for sensing toxic gases ${ }^{1}$. Transition metal oxide has been widely used as a sensing electrode for various reasons, including its flexibility of production, simplicity of use, its ability to catalyze a large number of gases, and its thermal and chemical stability ${ }^{2-5}$. Noble metal oxides are widely used as additives or sensitizers to improve the sensing performance of functional materials ${ }^{6}$. Few reports consider the unique properties of palladium oxide $(\mathrm{PdO})$ and its performance in gas sensing as a functional element ${ }^{7,8}$.

In our previous work ${ }^{8}, \mathrm{PdO}^{\prime}$ s performance as a sensing electrode was explored based on a YSZ ( $8 \%$ ( $x$, molar fraction) Yttriastabilized Zirconia) electrolyte, which was measured via a potentiometry method to detect carbon monoxide (CO). Attractive phenomena were observed. Changes in the electric potential of the sensor in a $\mathrm{CO}$ environment are independent of the mobile oxygen in the electrolyte and the thickness of the PdO electrode. A hypothesis is proposed that a potentiometric sensor based on a $\mathrm{PdO}$ electrode works in capacitive mode during a sensing process.

The working mechanism of a potentiometric sensor with a PdObased electrode is our focus in this paper. In order to verify the hypothesis, several aspects of the working principle were studied by experimental methods. First, PdO was doped by Ni, La, and $\mathrm{Mg}$. The doping is capable of shrinking the particle size of PdO and creating defects in PdO. The influence on the sensing performance of the sensor was discussed. Second, zirconia was replaced by other materials to test the impact of the electrolyte on the sensing performance. Third, the source of the sensing signal was located by measuring the impedance and resistance. The working model of the sensors with PdO-based electrodes is discussed.

\section{Materials and methods}

\subsection{Materials preparation}

$\mathrm{Pd}\left(\mathrm{C}_{2} \mathrm{H}_{3} \mathrm{O}_{2}\right)_{2}, \mathrm{Ni}\left(\mathrm{NO}_{3}\right)_{2} \cdot 6 \mathrm{H}_{2} \mathrm{O}, \mathrm{La}\left(\mathrm{NO}_{3}\right)_{3} \cdot 6 \mathrm{H}_{2} \mathrm{O}$ and $\mathrm{Mg}\left(\mathrm{NO}_{3}\right)_{2} \cdot$ $6 \mathrm{H}_{2} \mathrm{O}$ were obtained from Sinopharm Chemical Reagent Co. Ltd., China. Y-type zeolite $(\mathrm{Na}-\mathrm{Y}, \mathrm{Si} / \mathrm{Al}$ molar ratio $=2.5)$ was pruchased from Alfa Aesar, China. The above chemical reagents were of analytical grade and used without further purification.

Three types of dopants are fabricated based on PdO. Elements used for doping are transition metal $\left(\mathrm{Ni}^{2+}\right)$, alkaline earth metal $\left(\mathrm{Mg}^{2+}\right)$, and rare earth metal $\left(\mathrm{La}^{3+}\right)$. The molar ratios of the palladium and doped elements are $100: 5,100: 10$, and $100: 15$, which are denoted by M-PdO-5, M-PdO-10, and M-PdO-15, respectively (where $\mathrm{M}$ represents the doped elements, i.e., $\mathrm{Ni}, \mathrm{Mg}$, La). The preparation is described in Ref.8: a certain quality of $\mathrm{Pd}\left(\mathrm{C}_{2} \mathrm{H}_{3} \mathrm{O}_{2}\right)_{2}$ is dissolved in alcohol by energetic stirring. A corresponding quality of doped element in nitrate is weighed and added to the palladium acetate solution. Hydrolysis is achieved by adding deionized water at $90^{\circ} \mathrm{C}$ for $2 \mathrm{~h}$. The obtained solution is centrifuged to precipitate the resulting material, and then dried in a box oven at $130{ }^{\circ} \mathrm{C}$ for $12 \mathrm{~h}$. The resulting sample is calcined at
$700{ }^{\circ} \mathrm{C}$ for $2 \mathrm{~h}$ in air.

\subsection{Material characterization}

X-ray diffraction (XRD, Bruker D8 Focus, Germany) patterns are obtained with $\mathrm{Cu} K_{\alpha}$ radiation $(0.1541 \mathrm{~nm})$. Scanning electron microscopy (SEM, Hitachi S-4800, Japan) is performed to obtain images of the samples. The stoichiometric ratio, as well as the quality percentage of the doping element in the samples, is analyzed with an energy dispersive spectrometer (EDS, QUANTAX 400, Germany). The impedance spectroscopy is measured with an Agilent 4284A (USA) at $100 \mathrm{mV}$ in the range of $25 \mathrm{~Hz}-1 \mathrm{MHz}$. The electrical resistance of the sensors was measured by a computer-controlled Agilent multimeter (Agilent 34405A, USA).

\subsection{Fabrication of the sensor}

YSZ and alumina chips (8\% (molar fraction) $\mathrm{Y}_{2} \mathrm{O}_{3}$ doped zirconia), fabricated by the Shanghai Institute of Ceramics (Chinese Academy of Sciences, China), are used as the electrolyte in the sensor. The YSZ and alumina discs measure $7 \mathrm{~mm} \times 7 \mathrm{~mm} \times 0.5$ $\mathrm{mm}$ and $7 \mathrm{~mm} \times 7 \mathrm{~mm} \times 0.8 \mathrm{~mm}$, respectively. For the reference electrode, commercial Pt paste (TR27905, Japan Tanaka Precious Metal Industries Ltd.) is applied to one side of the YSZ by screen printing, and then dried at $130{ }^{\circ} \mathrm{C}$ for $20 \mathrm{~min}$. The Pt reference electrode, which is considered an ideal reversible electrode ${ }^{9}$, is sintered at a temperature of $1200{ }^{\circ} \mathrm{C}$ for $2 \mathrm{~h}$. The prepared PdObased samples and $\alpha$-terpineol are mixed to obtain the sensing electrode paste, which is screen printed on the other side of the YSZ and sintered at $700{ }^{\circ} \mathrm{C}$ for $2 \mathrm{~h}$. Finally, both electrodes are attached with Pt lead wires. Sensing electrodes with areas of $3 \mathrm{~mm} \times 3 \mathrm{~mm}\left(9 \mathrm{~mm}^{2}\right), 5 \mathrm{~mm} \times 5 \mathrm{~mm}\left(25 \mathrm{~mm}^{2}\right)$, and $7 \mathrm{~mm} \times 7$ $\mathrm{mm}\left(49 \mathrm{~mm}^{2}\right)$ are created by screen printing. If there are no special instructions, the size of the sensing electrode is $5 \mathrm{~mm} \times 5 \mathrm{~mm}$. The structure and image of the sensors are shown in Fig.1.

Y-type zeolite is a microporous, crystalline aluminosilicate that has mobile sodium cations inside the framework ${ }^{10}$. The zeolite pellets are prepared by pressing $200 \mathrm{mg}$ of zeolite powder under $5 \mathrm{t}$ of uniaxial force, and then sintered at $700{ }^{\circ} \mathrm{C}$ for $2 \mathrm{~h}$. The processes involved in the preparation of the sensor with zeolite are the same as those previously described, with the exception of the sintering temperature for the Pt reference electrode, which is $700{ }^{\circ} \mathrm{C}$. The framework of zeolite will collapse at a temperature higher than $800^{\circ} \mathrm{C}^{10}$.

\subsection{Sensing apparatus}

The sensor is placed in a hermetic quartz tube and heated under different temperatures, which are controlled by a temperature controller and heater in a tubular furnace. The flow rate of different gases is controlled independently by using computercontrolled electronic mass flow controllers (D07-19B, Seven Star Electronics, China). During the test, the total flow rate is maintained at $100 \mathrm{~mL} \cdot \mathrm{min}^{-1}$, and the sensing and reference electrodes are exposed to the same atmosphere. The electric potential $(V)$ between the sensing and reference electrodes is recorded by using a multifunction data acquisition card (USB-6221, National Instruments, USA). The response of the potentiometric sensor is measured as the difference in potential $(\Delta V)$ between the sensors 

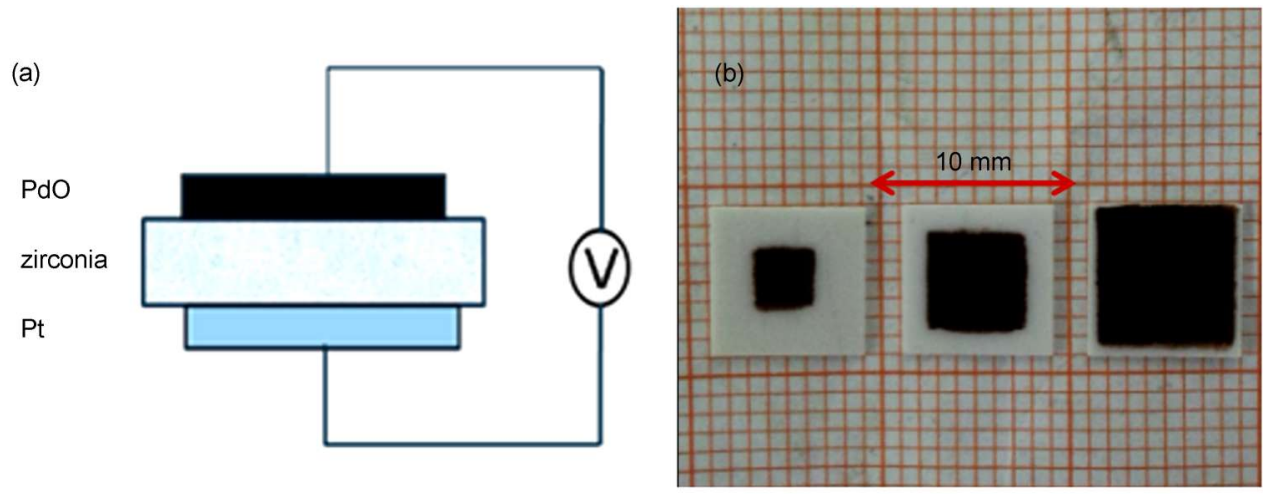

Fig.1 (a) Basic schematic of the sensor and (b) photo of the sensors with different areas of sensing electrode

in the background gas $\left(\mathrm{N}_{2}\right.$ and $5 \%\left(\varphi\right.$, volume fraction) $\mathrm{O}_{2}$ are usually used) and in the targeted gas. The positive terminal is always connected to the PdO-based electrode, and the negative terminal is connected to the Pt electrode.

\section{Results}

\subsection{Doping effects on PdO electrode}

Since $\mathrm{PdO}$ will decompose to metallic $\mathrm{Pd}$ at approximately $800{ }^{\circ} \mathrm{C}^{11}$, PdO-based dopants are prepared at $700{ }^{\circ} \mathrm{C}$. XRD patterns of pure and doped PdO are shown in Fig.2 and Fig.S1 (see Supporting Information). All diffraction peaks coincide with the corresponding peaks of $\mathrm{PdO}$ given in the standard data file (JCPDS File No. 43-1024). No peaks corresponding to the oxidic dopant are observed, even for the $15 \%$ ( $x$, molar fraction) doped samples. This may occur because of the small mass percentage of dopant in the samples. The peaks become broader and weaker when $\mathrm{Ni}$ is doped. Peak positions and full width at half maximum (FWHM) are used to determine the cell parameters and crystallite sizes for all palladium oxide ${ }^{12}$. The lattice parameters for all samples are calculated from the XRD peak positions in Fig.2 and are listed in Table 1. The cell volume has an initial increase during the incorporation of $\mathrm{Ni}$, and then decreases with the increasing doping concentration.

Typical SEM images of pure and Ni-doped PdO are shown in Fig.3 $(a-d)$. The grain becomes smaller as the level of doping increases. The average particle sizes are estimated to be $\sim 90, \sim 72$,

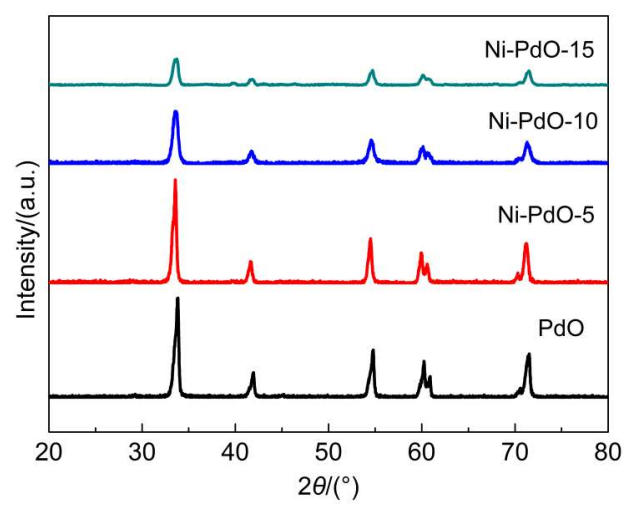

Fig.2 XRD patterns of pure and Ni-doped PdO $\sim 59$, and $\sim 50 \mathrm{~nm}$ for $\mathrm{PdO}$ and the dopants Ni-PdO-5, Ni-PdO-10, and Ni-PdO-15, respectively. Agglomerates are clearly observable, and they cause a random spatial distribution. The images of the surfaces of the YSZ disc and the Na-Y pellet are shown in Fig.3(e, f)

To investigate the relationship between the defects of $\mathrm{PdO}$ and the sensing performance of the sensors, an EDS analysis of pure and $\mathrm{Ni}$-doped $\mathrm{PdO}$ is carried out to study the impact of the doping. The results in Table 2 indicate that the samples are non-stoichiometric, and the atomic ratio of $\mathrm{Pd} / \mathrm{Ni}$ increases with the doping level. Moreover, the largest oxygen vacancy is observed on the surface of Ni-PdO-10.

The role of a dopant is to disrupt the chemical bonds on the surface of the host oxide to ready the doped oxide for chemical interaction $^{13,14}$. In the case of Ni-doped PdO, according to XRD patterns and SEM images, the crystals become smaller as the doping content increases. Comparing the relative ionic radius of $\mathrm{Pd}^{2+}(0.064 \mathrm{~nm})$ and $\mathrm{Ni}^{2+}(0.069 \mathrm{~nm})$, substituting $\mathrm{Ni}$ into the $\mathrm{Pd}$ positions would increase the unit cell volume. The experimental trend shows an initial increase in unit cell volume, with a decrease that follows the doping content, as shown in Table 1. It is also noticeable that the unit cell volumes of all $\mathrm{Ni}$-doped samples are larger than the undoped volumes. Combining the atomic ratios on the surface obtained by EDS in Table 2, the ratio of Ni increases with the doping level. When the host oxide suffers heavy doping, the dopant tends to be segregated and forms a layer of oxide clusters that heal the oxygen vacancies on the surface ${ }^{13}$. By contrast, a lower concentration of dopant will solid-dissolve into the crystal of PdO and expand its unit cell volume ${ }^{14-16}$. At the same time, a solid solution will create more defects by crystal distor$\operatorname{tion}^{17,18}$.

Various sensing electrodes made by PdO-based dopants on YSZ are tested in $\mathrm{CO}$ environments. The sensing responses for $100 \times$

Table 1 Measured lattice parameters of Ni-doped PdO

\begin{tabular}{cccccc}
\hline Ni-doped PdO & $a / \mathrm{nm}$ & $b / \mathrm{nm}$ & $c / \mathrm{nm}$ & Volume $/ \mathrm{nm}^{3}$ & Density $/\left(\mathrm{g} \cdot \mathrm{cm}^{-3}\right)$ \\
\hline PdO & 0.30429 & 0.30429 & 0.53347 & 0.04941 & 8.2293 \\
Ni-PdO-5 & 0.30547 & 0.30547 & 0.53482 & 0.04991 & 8.1454 \\
Ni-PdO-10 & 0.30530 & 0.30530 & 0.53353 & 0.04973 & 8.1744 \\
Ni-PdO-15 & 0.30441 & 0.30441 & 0.53478 & 0.04953 & 8.2063 \\
\hline
\end{tabular}



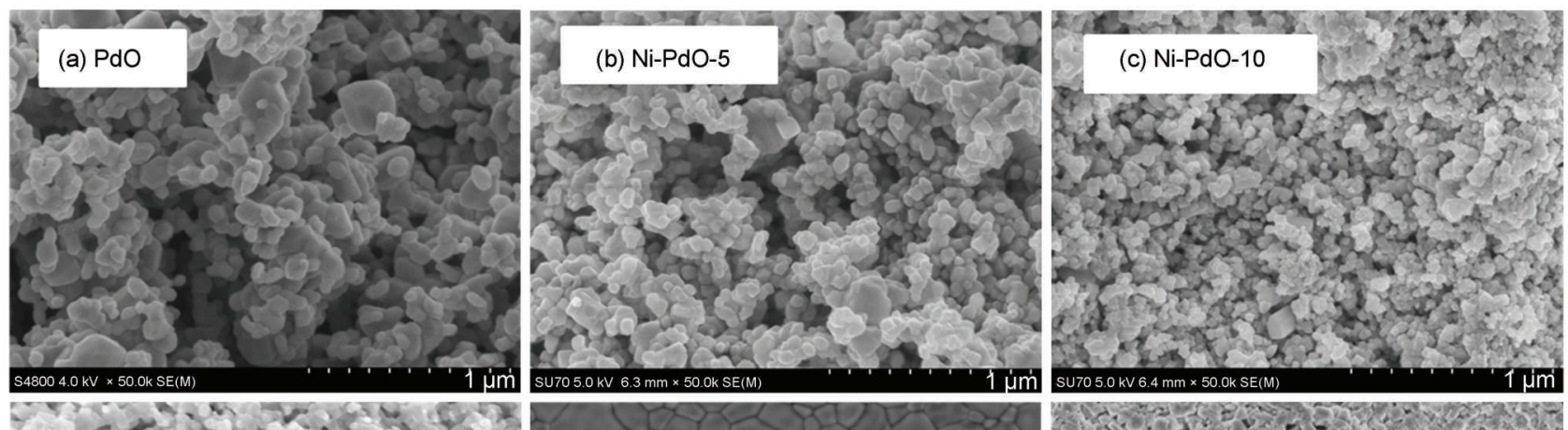

(d) Ni-PdO-15
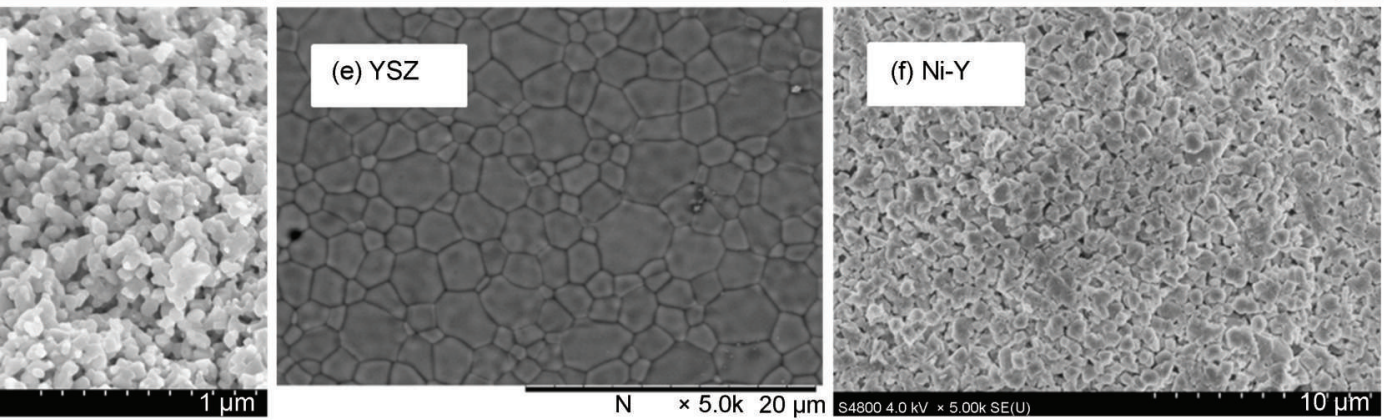

Fig.3 SEM images of (a) PdO and dopants with different levels of doping (b) Ni-PdO-5, (c) Ni-PdO-10, and

(d) Ni-PdO-15; (e) surface of YSZ disc, and (f) Na-Y pellet

$10^{-6}$ (volume fraction) $\mathrm{CO}$ are given in Fig.4. A general improvement is observed for the sensors with $\mathrm{Ni}$ - and La-doped $\mathrm{PdO}$ electrodes in the range of $400-550{ }^{\circ} \mathrm{C}$. The best working temperature is in the range of 450 to $500{ }^{\circ} \mathrm{C}$. At temperatures above $500{ }^{\circ} \mathrm{C}$, the sensors' responses decay. The doped electrodes, in which Pd and foreign elements are present in a molar ratio of 100 : 5 , have the best performance. In particular, the best $\mathrm{CO}$ sensor uses $\mathrm{Ni}$-doped $\mathrm{PdO}$ at $450^{\circ} \mathrm{C}$. Hereafter, the sensor made of a NiPdO-5 sensing electrode is used to conduct the study in this paper.

For the sensing test in Fig.4, the Ni- and La-doped PdO behaves better than the undoped version. Despite an increasing response observed for the sensors with $\mathrm{Ni}$ - and La-doped PdO electrodes, different active sites are brought into the samples by $\mathrm{La}, \mathrm{Ni}$, and $\mathrm{Mg}$. According to the classification of dopant-oxide pairs ${ }^{13}, \mathrm{La}$ is a high-valence dopant (HVD), while $\mathrm{Mg}$ and $\mathrm{Ni}$ are same-valance dopants (SVD). HVD intends to adsorb $\mathrm{O}_{2}$ from a gas phase at the vacant sites, and activates it. Thus, a reducing gas can react with this oxygen and undergo oxidation. In the case of SVD, since $\mathrm{MgO}$ is irreducible and the valence of $\mathrm{Ni}$ is flexible, it could be predicted that the flexible- valance dopant is favorable for promoting the mobility of oxygen vacancies. The sensing signal of conventional potentiometric sensors can be effectively improved by decreasing the surface area of the grains of the sensing elec-

Table 2 Element contents of pure and Ni-doped PdO samples

\begin{tabular}{ccccc}
\hline \multirow{2}{*}{ Sample series } & \multicolumn{3}{c}{ Molar fraction/\% } & \multirow{2}{*}{ Formula } \\
\cline { 2 - 4 } & palladium & oxygen & nickel & \\
\hline PdO & 56.48 & 43.52 & & $\mathrm{PdO}_{0.77}$ \\
Ni-PdO-5 & 63.16 & 34.79 & 2.04 & $\mathrm{Pd}_{0.97} \mathrm{Ni}_{0.03} \mathrm{O}_{0.53}$ \\
Ni-PdO-10 & 67.52 & 27.40 & 5.08 & \\
Ni-PdO-15 & 44.64 & 43.67 & 11.79 & $\mathrm{Pd}_{0.93} \mathrm{Ni}_{0.07} \mathrm{O}_{0.38}$ \\
\hline
\end{tabular}

trode and increasing the contact area of triple phase boundary $(\mathrm{TPB})^{19}$. However, the response was enhanced by creating oxygen vancancies in the $\mathrm{PdO}$ electrode in our study. The oxygen vacancies are the sites for the catalytic oxidation between $\mathrm{CO}$ and adsorbed ionic oxygen ${ }^{6}$.

An $\mathrm{O}_{2}$-dependent experiment is conducted on the sensor at $450{ }^{\circ} \mathrm{C}$, as shown in Fig.5. As can be seen, the increasing percentage of $\mathrm{O}_{2}$ in the environment leads to a rise in the baseline of the sensor. The average increase is $12 \mathrm{mV}$ when the $\mathrm{O}_{2}$ concentration doubles. In the meantime, the response of the sensor toward $100 \times 10^{-6}$ (volume fraction) of $\mathrm{CO}$ decreases by approximately $4 \mathrm{mV}$ because of the increase in the $\mathrm{O}_{2}$ concentration. $\mathrm{O}_{2}$ does interfere significantly with the sensing performance.

Sensing electrodes with different areas are tested, and the results for $\mathrm{CO}$ detection at $450{ }^{\circ} \mathrm{C}$ are given in Fig.6. When the responses are plotted versus $\mathrm{CO}$ concentrations on a logarithmic scale, the relationship is linear. The responses for all sensors increase as the $\mathrm{CO}$ concentration increases. Moreover, the sensitivities of the sensors, which are the slopes of the plots in Fig.6, are $-30.36,-38.21$, and $-38.77 \mathrm{mV} \cdot \mathrm{decade}^{-1}$ for sensors with sensing electrodes having areas of 9,25 , and $49 \mathrm{~mm}^{2}$, respectively. The increasing sensing area leads to a higher response.

Moreover, a potentiometric sensor based on coupling a solid electrolyte with semiconducting oxides is explained by the mixed potential theory ${ }^{20}$, which assumes a thermodynamic potential independent of the size of the electrode ${ }^{21}$. However, the potential is typically proportional to the area of the sensing electrode, as shown in Fig.6. These results lead us to think that the sensing reactions in the sensor with a $\mathrm{PdO}$-based electrode are of the capacitance type.

\subsection{Role of electrolyte in gas sensing}



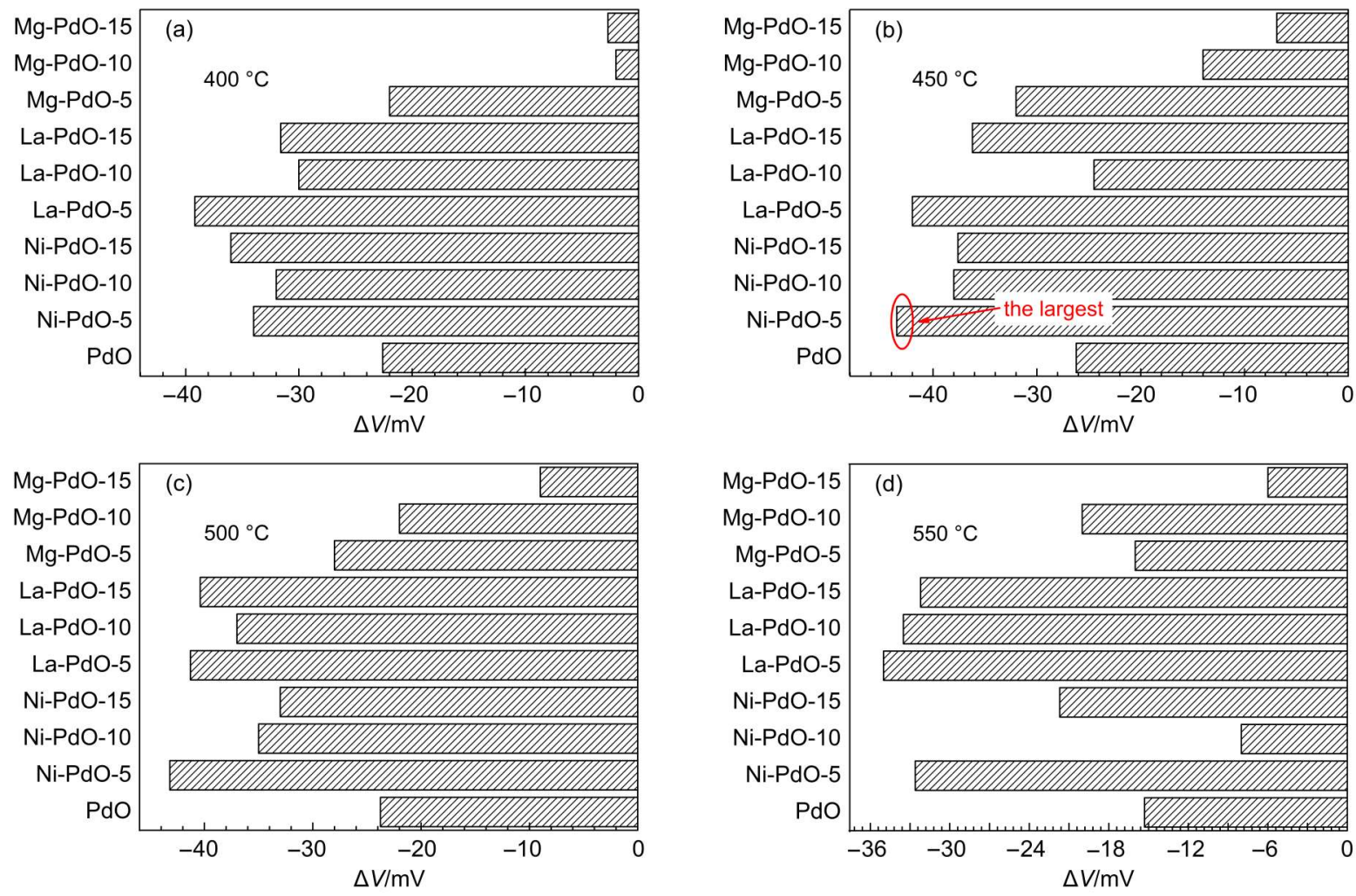

Fig.4 Sensing response of potentiometric sensor with doped PdO electrode to $\mathrm{CO}$ at (a) $400{ }^{\circ} \mathrm{C}$, (b) $450{ }^{\circ} \mathrm{C}$, (c) $500{ }^{\circ} \mathrm{C}$, and (d) $550{ }^{\circ} \mathrm{C}$, balanced by $\mathrm{N}_{2}$ and $5 \% \mathrm{O}$

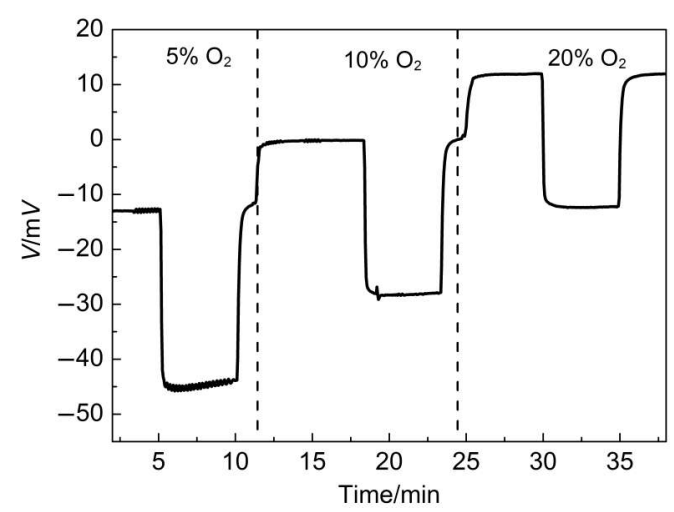

Fig.5 Electric potential change for sensor with Ni-PdO-5 electrode to $100 \times 10^{-6}$ (volume fraction) $\mathrm{CO}$ balanced by $5 \%$, $10 \%$, and $20 \%$ (volume fraction) $\mathrm{O}_{2}$ and $\mathrm{N}_{2}$ at $450{ }^{\circ} \mathrm{C}$

In order to address the role of electrolyte in gas sensing, a $\mathrm{Ni}$ PdO-5 electrode was printed on an alumina disc and zeolite pellet, and tested in a $\mathrm{CO}$ environment at $450{ }^{\circ} \mathrm{C}$. The potentiometric results of the sensor based on the alumina disc are shown in Fig. S2 (see Supporting Information). No potentiometric response is observed for the sensor printed on the alumina disc. Potentiometric responses for the sensor based on zeolite are obtained for $100 \times 10^{-6}, 200 \times 10^{-6}$, and $400 \times 10^{-6}$ (volume fraction) of $\mathrm{CO}$, as shown in Fig.7(a). Next, an $\mathrm{O}_{2}$ dependence experiment is conducted. The sensor is tested in $100 \times 10^{-6}$ (volume fraction) $\mathrm{CO}$ under $5 \%, 10 \%$, and $15 \% \mathrm{O}_{2}$, as shown in Fig. 7(b). A depressive

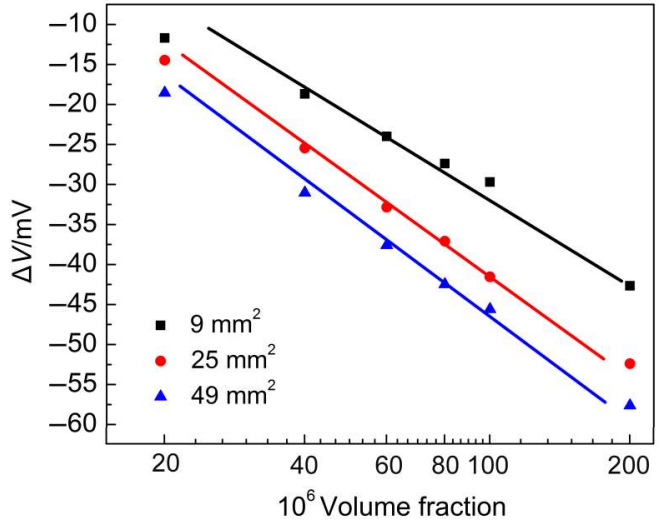

Fig.6 Dependence of $\Delta \boldsymbol{V}$ for sensors with different areas of sensing electrode on $\mathrm{CO}$ concentrations balanced by $5 \% \mathrm{O}_{2}$ and $\mathrm{N}_{2}$ at $450{ }^{\circ} \mathrm{C}$

response to $\mathrm{CO}$ and a rising baseline with increasing $\mathrm{O}_{2}$ are noticed. Moreover, Ni-PdO-5 electrodes on YSZ and Na-Y have sensing profiles similar to those from the oxygen-dependent measurement. Ionic material is essential to generate a potentiometric response to $\mathrm{CO}$. In other words, the changing of the chemical potential gradient in the electrolyte is the source of the sensing signal.

\subsection{Source of the sensing signal}

A solid-state potentiometric sensor for gas sensing is commonly explained by the mixed potential theory ${ }^{20}$. When the sensor is exposed to a targeted species, more than one cathodic or anodic 

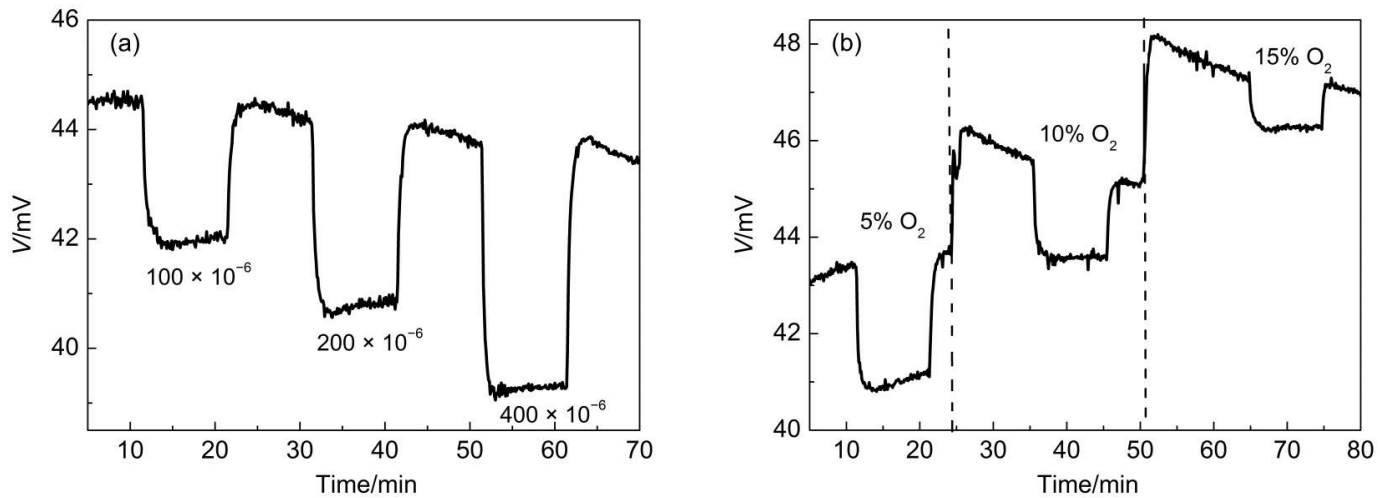

Fig.7 Potentiometric response of sensor combined with Ni-PdO-5 sensing electrode and Na-Y electrolyte to (a) $100 \times 10^{-6}, 200 \times 10^{-6}$, and $400 \times 10^{-6}$ (volume fraction) $\mathrm{CO}$ balanced with $5 \% \mathrm{O}_{2}$ and $\mathrm{N}_{2}$ and (b) $100 \times 10^{-6}$ (volume fraction) $\mathrm{CO}$ in $5 \%, 10 \%$, and $15 \% \mathrm{O}_{2}$ at $450{ }^{\circ} \mathrm{C}$

reaction between the targeted species and components of the electrolyte occurs at the interface of the electrode/electrolyte, which is the so-called TPB. The resulting electrode potential becomes a mixed potential ${ }^{22}$. The following pair of reactions (1) and (2) occur at the interface of the sensing electrode/zirconia for gas sensing:

$$
\begin{aligned}
& \mathrm{Re}(\mathrm{g})+\mathrm{O}^{2-}(\text { electrolyte }) \rightleftharpoons \mathrm{Ox}(\mathrm{g})+n \mathrm{e}^{-}(\text {electrode }) \\
& \mathrm{O}_{2}+n \mathrm{e}^{-}(\text {electrode }) \rightleftharpoons n \mathrm{O}^{2-}(\text { electrolyte })
\end{aligned}
$$

where $\operatorname{Re}(\mathrm{g})$ and $\mathrm{Ox}(\mathrm{g})$ represent a targeted gas in its reduced and oxidized forms, respectively.

To investigate the ionic motion of the potentiometric sensor during sensing process, impedance is carried out to measure the ionic conductivity of the sensors under variational $\mathrm{CO}$ or $\mathrm{O}_{2}$ en- vironment as shown in Fig.8. Since palladium oxide is a good electrical conductor, the measured impedance belongs to the electrolyte. For the measurements on the sensor with YSZ in Fig.8 $(a, b)$, the shift of the impedance in different $\mathrm{CO}$ concentrations, within experimental error, is negligible.

If the oxygen ions from the electrolyte participate in the electrochemical reactions, the impedance change in the electrolyte can be observed. However, the ionic conductivity decreases when oxygen is enriched in the environment. This occurs because more $\mathrm{O}^{2-}$ enters the electrolyte ${ }^{23}$. This result agrees well with the electric potential increase of the potentiometric sensor, as shown in Fig.5. No shift of impedance is observed in the CO environment; thus, the number of oxygen ions in the electrolyte and their respective
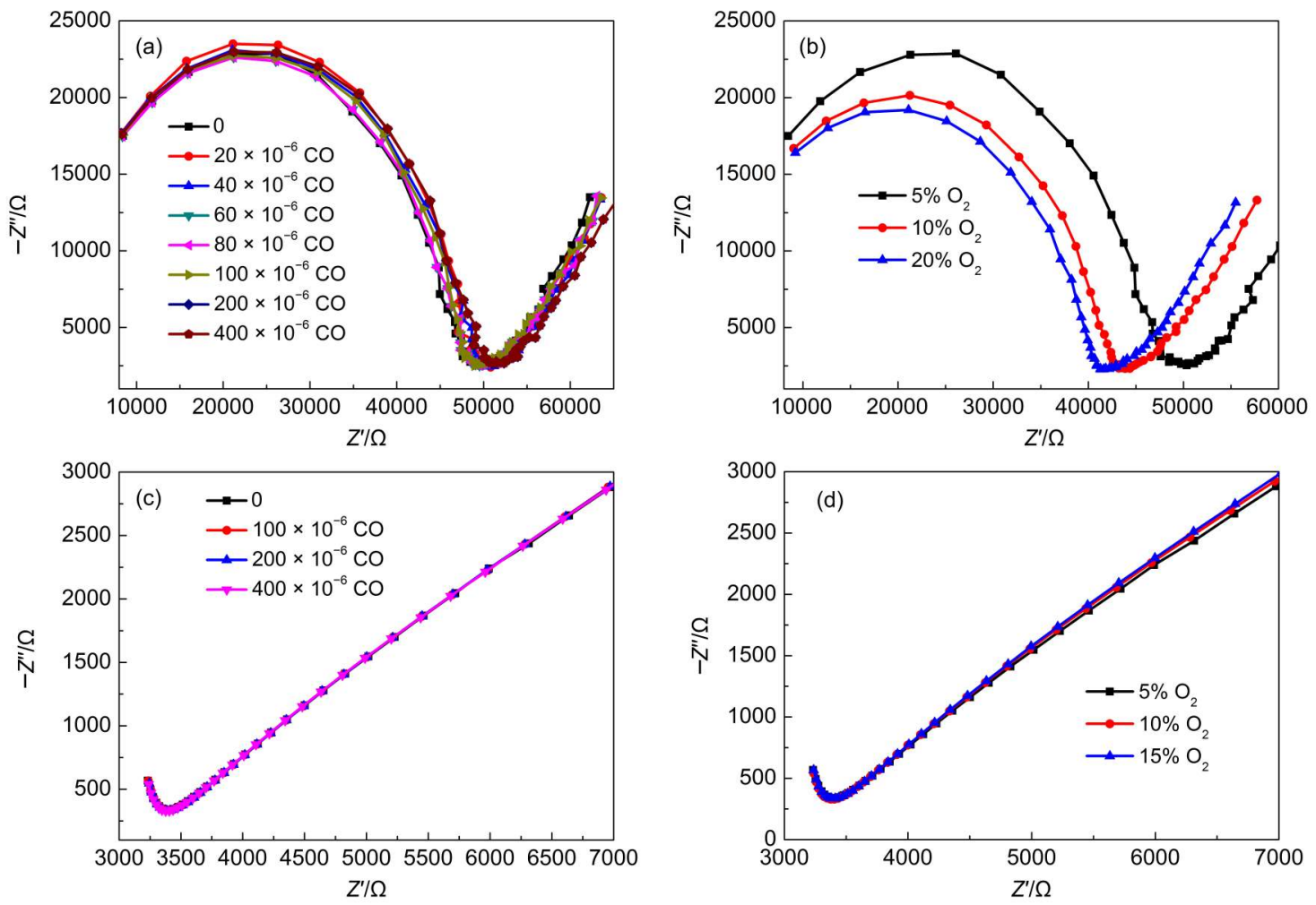

Fig.8 Complex impedance spectra of sensor on YSZ in different (a) $\mathrm{CO}$ and (b) oxygen concentrations, and sensor with Na-Y in different (c) $\mathrm{CO}$ and (d) oxygen concentrations within frequency range from $1 \mathrm{MHz}$ to $25 \mathrm{~Hz}$ at $450{ }^{\circ} \mathrm{C}$ 
mobility are not disturbed during the electrochemical reactions. For the sensor with zeolite, the impedance is constant under different gaseous environments, as shown in Fig.8(c, d). The results indicate that sodium ions in zeolite will not be influenced by the gaseous species in the environment.

The mobile ions inside the electrolyte are essential for the generation of a potentiometric response. Since ionic flows from the chemical potential gradient are balanced by the electric field gradient ${ }^{24}$, the changing resistance across the sensors reflects the change in the chemical potential gradient under $\mathrm{CO}$ sensing processes. The electrical resistivity across the sensors decreases for both sensors when $\mathrm{CO}$ is introduced (Fig.9). The resistance of the sensors is a series of Pt reference electrode, electrolyte, PdObased electrode, and their interfacial barrier. To address the source of the change in resistances of the sensors, a resistance of Ni-PdO5 is measured for $100 \times 10^{-6}$ (volume fraction) $\mathrm{CO}$ at $450^{\circ} \mathrm{C}$ in Fig. S3 (see Supporting Information). The result indicates that no net electrons transfer between $\mathrm{CO}$ and $\mathrm{PdO}$ in the equilibrium state. Accordingly, the interfacial barrier between the sensing electrode and electrolyte decreases owing to $\mathrm{CO}$ adsorption. Therefore, the interfacial potential increase between the sensing electrode and electrolyte is the source of the potentiometric response.

\section{Discussion}

Based on the previous results and discussion, capacitive behaviors were observed for the potentiometric sensor with a PdO-
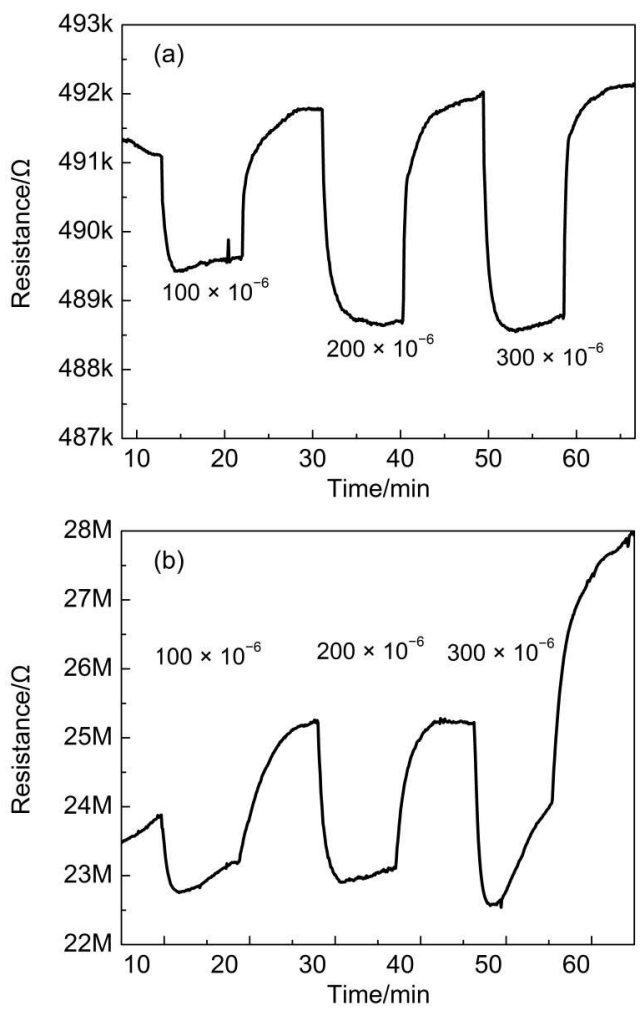

Fig.9 Resistance change across sensors to $100 \times 10^{-6}$, $200 \times 10^{-6}$, and $300 \times 10^{-6}$ (volume fraction) $\mathrm{CO}$ balanced by $5 \% \mathrm{O}_{2}$ and $\mathrm{N}_{2}$ at $450{ }^{\circ} \mathrm{C}$

(a) sensor with YSZ electrolyte, (b) sensor with Na-Y electrolyte based electrode. When $\mathrm{PdO}$ is brought into contact with a ionic conductor, an electrochemical double layer appears ${ }^{25}$. The potential drop across the electrochemical double layer can be interpreted as

$$
\Delta \Phi=\frac{k_{\mathrm{B}} T}{q} \ln \left(\frac{\rho_{\mathrm{PdO}}}{\rho_{\text {electrolyte }}}\right)
$$

where $k_{\mathrm{B}}$ is the Boltzmann constant, $T$ is the temperature, $q$ is elementary charge, and $\rho_{\text {electrolyte }}$ and $\rho_{\mathrm{PdO}}$ are the charge densities on the surface of $\mathrm{PdO}$ and the electrolyte, respectively.

The capacitance of the electrochemical double-layer is described by

$$
C=\left(\frac{A}{d}+L \delta\right) \varepsilon
$$

where $A$ is the area of the electrochemical double layer, $d$ is the distance between them, $L$ is the perimeter of the PdO electrode, $\delta$ is the edge effect in the capacitor, $\varepsilon$ is the permittivity.

The catalytic oxidation of $\mathrm{CO}$ over $\mathrm{PdO}$ is expressed in equations $(5)-(7)^{26,27}$. The reactions could be described as follows ${ }^{27,28}$ : oxygen and carbon monoxide from the gas phase co-adsorbed at the vacant sites on the surface of the $\mathrm{PdO}$, and interacted to form intermediates (e.g., "carbonate”), which will decompose to form $\mathrm{CO}_{2}$ and heal oxygen vacancies.

$$
\begin{aligned}
\mathrm{O}_{2(\mathrm{~g})}+n \mathrm{e}^{-} \rightarrow(1 \leq n \leq 2) \\
\mathrm{CO}_{(\mathrm{g})}+\mathrm{e}^{-} \rightarrow \mathrm{CO}_{(\mathrm{ad})}^{-} \\
\mathrm{CO}_{(\mathrm{ad})}^{-}+2 \mathrm{O}_{(\mathrm{ad})}^{n-} \rightarrow\left[\mathrm{CO}_{3}\right]_{(\mathrm{ad})}^{2-}+(2 n-1) \mathrm{e}^{-} \rightarrow \\
\mathrm{CO}_{2(\mathrm{~g})}+\mathrm{O}_{(\mathrm{ad})}^{2-}+(2 n-1) \mathrm{e}^{-}
\end{aligned}
$$

During the catalytic oxidation, the ionic species are redistributed on the surface of $\mathrm{PdO}$, the electrons shift between $\mathrm{PdO}$ and $\mathrm{CO}$ and $\mathrm{O}_{2}$, and mobile positive ions from the volume of electrolyte move toward the PdO-based electrode. If the mobile ions

(a)

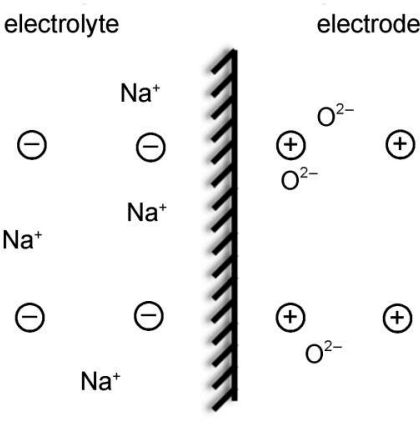

(b)

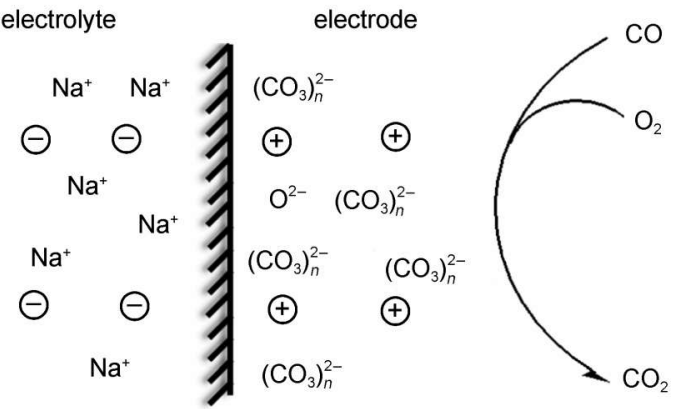

Fig.10 Schematic of mechanism to explain the response of potentiometric sensor constructed by $\mathrm{Na}-\mathrm{Y}$ and PdO-based electrode under different conditions

(a) sensor in background gas, (b) sensor exposed to $\mathrm{CO}$ 
are negative, they will move from the surface into the volume of the electrolyte. During the sensing process, the charge density at the interface and the distribution of potential inside the electrolyte are altered. The degree of the alteration is related to the concentration of CO. Therefore, the potential change at the interface is linearly dependent on the logarithmic concentration of $\mathrm{CO}$ according to the equation (3). Moreover, a higher sensitivity of the sensor with larger area of PdO electrode is observed in the Fig.6. According to the equation (4), the capacitance will increase with the increasing area of $\mathrm{PdO}$ electrode because of the edge effect in the capacitance. A higher capacitance is capable to hold more ionic species, which are favorable for the reactions at the interficial of $\mathrm{PdO}$ electrode and the electrolyte. Therefore, the charge density $\left(\rho_{\text {PdO }}\right)$ is increased due to the edge effect, then it will lead to a higher sensitivity. A simplistic model uses the sensor with $\mathrm{Na}-\mathrm{Y}$ as an example, and is shown in Fig. 10.

\section{Conclusions}

Potentiometric sensors based on noble metal oxide electrodes are an emerging field that is still awaiting consolidation and rationalization. A PdO sensing electrode, printed on YSZ and Na-Y, shows a potentiometric response to changes in $\mathrm{CO}$ partial pressure. Doping on PdO could result in a fair improvement in the sensing performance owing to the creation of defects, which would aid in the improvement of the oxidation reaction. The potentiometric response of sensors is ascribed to the interfacial potential between the PdO-based electrode and the electrolyte, e.g., zirconia and zeolite. The most important question is this: What qualities make PdO different from other metal oxides as a sensing electrode? The crystal of PdO has a sub-micro size, thus the PdO electrode has a larger surface area than the oxide electrode used in other literature ${ }^{29,30}$. Furthermore, PdO has excellent catalytic activity; thus, gas molecules will be consumed before they reach the TPB. Finally, the relatively weak metal oxygen bonding in PdO could facilitate the transport of oxygen vacancies and the adsorption of charged species. It is advisable to study PdObased electrodes with other electrolytes to explore more applications of solid-state electrochemical sensors.

Supporting Information: available free of charge via the internet at http://www.whxb.pku.edu.cn.

\section{References}

(1) Park, C. O.; Fergus, J. W.; Miura, N.; Park, J.; Choi, A. Ionics 2009, 15, 261. doi: 10.1007/s11581-008-0300-6

(2) Di Bartolomeo, E.; Grilli, M. L.; Traversa, E. J. Electrochem. Soc. 2004, 151, H133. doi: 10.1149/1.1695387

(3) Di Bartolomeo, E.; Grilli, M. L.; Yoon, J. W.; Traversa, E. J. Am. Chem. Soc. 2004, 87, 1883. doi: $10.1111 / j .1151-$ 2916.2004.tb06335.x

(4) Tang, W.; Wang, J.; Yao, P. J.; Du, H. Y.; Sun, Y. H. Acta Phys. -Chim. Sin. 2014, 30 (4), 781. [唐 伟, 王 兢, 姚朋军,
杜海英, 孙炎辉. 物理化学学报, 2014, 30 (4), 781.]

doi: 10.3866/PKU.WHXB201402191

(5) Feng, Q. X.; Yu, P.; Wang, J.; Li, X. G. Acta Phys. -Chim. Sin. 2015, 31 (12), 2405. [冯秋霞, 于 鹏, 王 競, 李晓干. 物理化 学学报, 2015, 31 (12), 2405.] doi: 10.3866/PKU. WHXB201510261

(6) Korotcenkov, G. Mat. Sci. Eng. B-Solid 2007, 139, 1. doi: 10.1016/j.mseb.2007.01.044

(7) Chiang, Y. J.; Pan, F. M. J. Phys. Chem. C 2013, 117, 15593. doi: 10.1021/jp402074w

(8) Zhu, L.; Zheng, Y.; Jian, J. Ionics 2015, 21, 2919. doi: 10.1007/ s11581-015-1487-y

(9) Zhang, W. F.; Schmidt-Zhang, P.; Guth, U. Solid State Ionics 2004, 169, 121. doi: 10.1016/j.ssi.2003.10.004

(10) Auerbach, S. M.; Carrado, K. A.; Dutta, P. K. Handbook of Zeolite Science and Technology; Marcel Dekker Inc.: New York, 2003.

(11) Zheng, Y.; Qiao, Q.; Wang, J.; Li, X.; Jian, J. Sens. Actuator BChem. 2015, 212, 256. doi: 10.1016/j.snb.2015.02.035

(12) Bukhari, S. M.; Giorgi, J. B. Solid State Ionics 2010, 181, 392. doi: 10.1016/j.ssi.2010.01.017

(13) McFarland, E. W.; Metiu, H. Chem. Rev. 2013, 113, 4391. doi: $10.1021 / \mathrm{cr} 300323 \mathrm{w}$

(14) Zheng, Y.; Wang, J.; Yao, P. Sens. Actuator B-Chem. 2011, 156, 723. doi: 10.1016/j.snb.2011.02.026

(15) Gurlo, A. Nanoscale 2011, 3, 154. doi: 10.1039/c0nr00560f

(16) Burbano, M.; Norberg, S. T.; Hull, S.; Eriksson, S. G.; Marrocchelli, D.; Madden, P. A.; Watson, G. W. Chem. Mater. 2011, 24, 222. doi: 10.1021/cm2031152

(17) Zhang, J.; Xie, K.; Wei, H.; Qin, Q.; Qi, W.; Yang, L.; Ruan, C.; Wu, Y. Sci. Rep. 2014, 4, 7082. doi: 10.1038/srep07082

(18) Kim, Y. M.; He, J.; Biegalski, M. D.; Ambaye, H.; Lauter, V.; Christen, H. M.; Pantelides, S. T.; Pennycook, S. J.; Kalinin, S. V.; Borisevich, A. Y. Nat. Mater. 2012, 11, 888. doi: 10.1038/ NMAT3393

(19) Elumalai, P.; Wang, J.; Zhuiykov, S.; Terada, D.; Hasei, M.; Miura, N. J. Electrochem. Soc. 2005, 152, H95. doi: 10.1149/ 1.1923707

(20) Mukundan, R.; Brosha, E. L.; Brown, D. R.; Garzon, F. H. J. Electrochem. Soc. 2000, 147, 1583. doi: 10.1149/1.1393398

(21) Stetter, J. R.; Li, J. Chem. Rev. 2008, 108, 352. doi: 10.1021/ cr0681039

(22) Garzon, F. H.; Mukundan, R.; Brosha, E. L. Solid-State Mixed Potential Gas Sensors: Theory, Experiments and Challenges; Elsevier: Kidlington, Royaume-Uni, 2000.

(23) Sridhar, S.; Stancovski, V.; Pal, U. B. Solid State Ionics 1997, 100, 17. doi: 10.1016/S0167-2738(97)00322-6

(24) Lim, D. K.; Im, H. N.; Song, S. J. Sci. Rep. 2016, 6, 18804. doi: 10.1038/srep18804

(25) Simon, P.; Gogotsi, Y. Nat. Mater. 2008, 7, 845. doi: 10.1038/ nmat2297 
(26) Gong, X. Q.; Hu, P.; Raval, R. J. Chem. Phys. 2003, 119, 6324. doi: $10.1063 / 1.1602053$

(27) Gabasch, H.; Knop-Gericke, A.; Schlogl, R.; Borasio, M.; Weilach, C.; Rupprechter, G.; Penner, S.; Jenewein, B.; Hayek, K.; Klotzer, B. Phys. Chem. Chem. Phys. 2007, 9, 533. doi: 10.1039/b610719b

(28) Weaver, J. F. Chem. Rev. 2013, 113, 4164. doi: 10.1021/ cr300323wl

(29) Macam, E. R.; Blackburn, B. M.; Wachsman, E. D. Sens. Actuator B-Chem. 2011, 157, 353. doi: 10.1016/j. snb.2011.05.014

(30) Miura, N.; Raisen, T.; Lu, G.; Yamazoe, N. J. Electrochem. Soc. 1997, 144, L198. doi: 10.1149/1.1344558 
Supporting Information for Acta Phys. -Chim. Sin. 2017, 33 (3), 573-581

doi: 10.3866/PKU.WHXB201612122

\title{
氧化钯作为电位型传感器中敏感电极的工作机理
}

郑雁公 ${ }^{1, *}$ 朱丽娜 ${ }^{1}$ 李晗宇 ${ }^{1} \quad$ 简家文 $^{1, *} \quad$ 杜海英 $^{2}$

( ${ }^{1}$ 宁波大学信息科学与工程学院, 浙江宁波 $315000 ;{ }^{2}$ 大连民族大学机电工程学院, 辽宁大连 116600)

\section{Operating Mechanism of Palladium Oxide as a Potentiometric Sensing Electrode}

\author{
ZHENG Yan-Gong ${ }^{1, *} \quad$ ZHU Li-Na ${ }^{1} \quad$ LI Han-Yu ${ }^{1} \quad$ JIAN Jia-Wen ${ }^{1, *}$ \\ DU Hai-Ying ${ }^{2}$ \\ $\left({ }^{1}\right.$ Faculty of Electrical Engineering and Computer Science, Ningbo University, Ningbo 315000, Zhejiang Province, \\ P. R. China; ${ }^{2}$ College of Mechanical and Electronic Engineering, Dalian Minzu University, Dalian 116600, \\ Liaoning Province, P. R. China)
}

*Corresponding authors. ZHENG Yan-Gong, Email: zhengyangong@nbu.edu.cn; Tel: +86-13216681910. JIAN Jia-Wen, Email: jianjiawen@ @bu.edu.cn; Tel: +86-13780047417. 

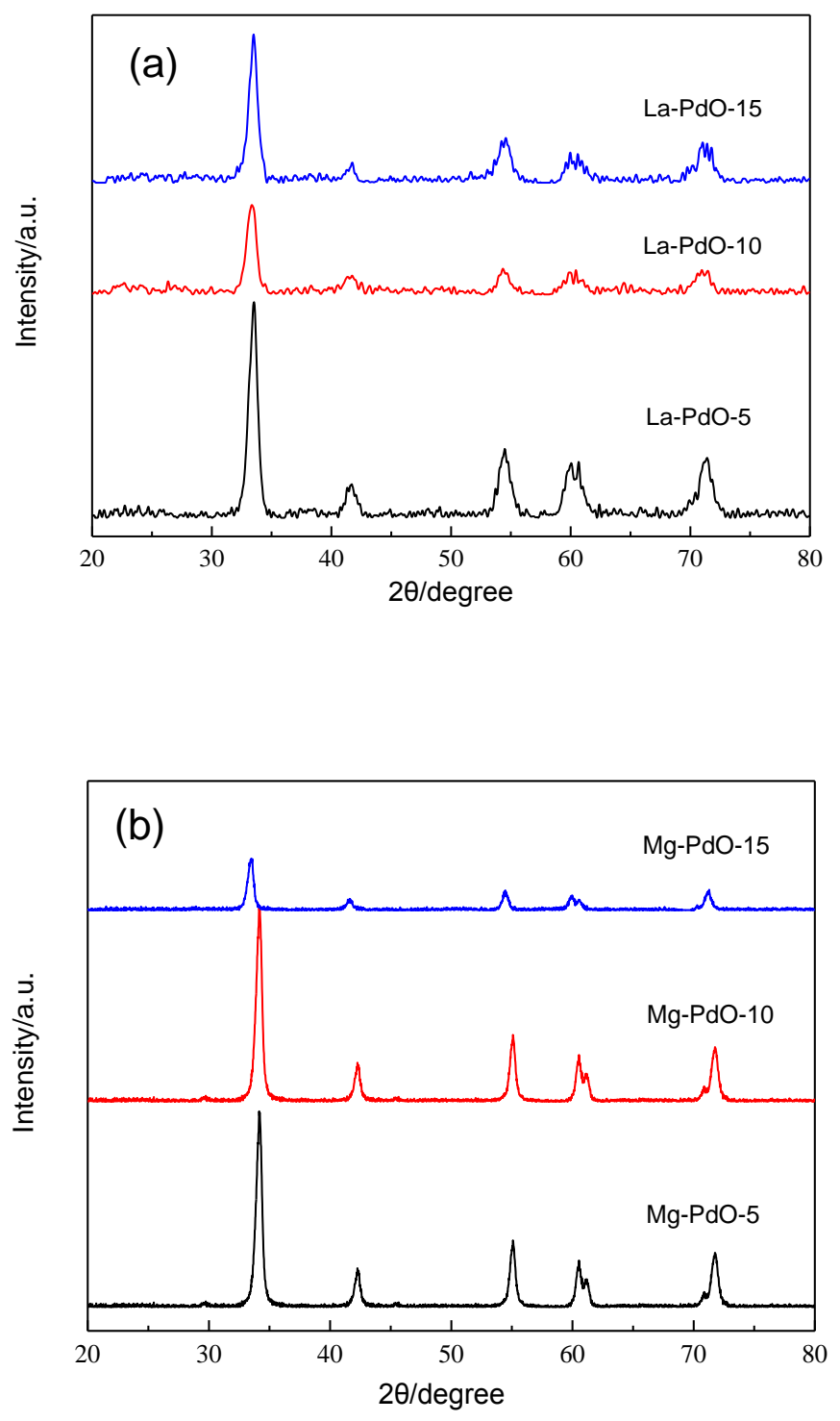

Fig.S1 XRD patterns of (a) La-doped PdO and (b) Mg-doped PdO 


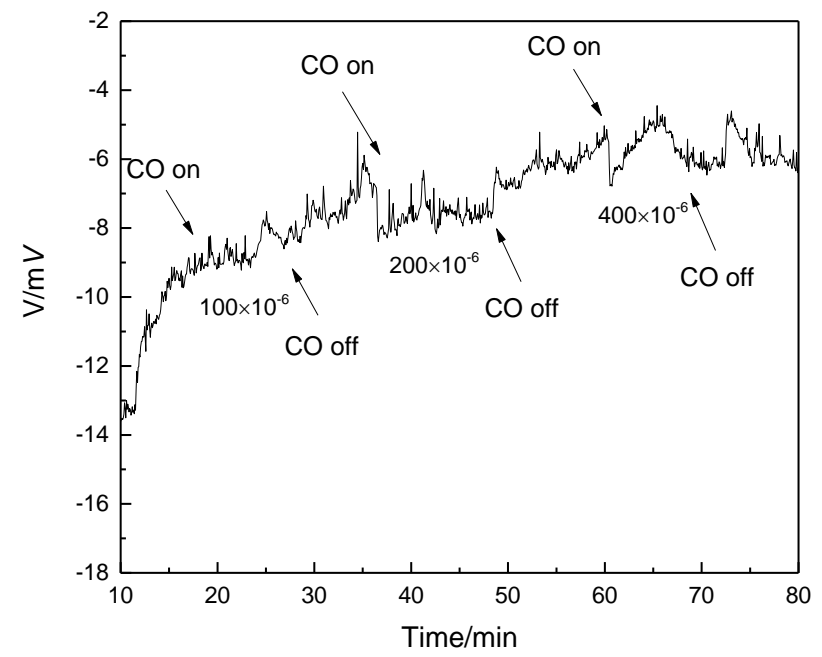

Fig.S2 Electric potential change for sensor coupled with the Ni-PdO-5 electrode and alumina disc to $100 \times 10^{-6}, 200 \times 10^{-6}$ and $400 \times 10^{-6}$ (volume fraction) $\mathrm{CO}$ balanced by $5 \% \mathrm{O}_{2}$ and $\mathrm{N}_{2}$ at $450{ }^{\circ} \mathrm{C}$

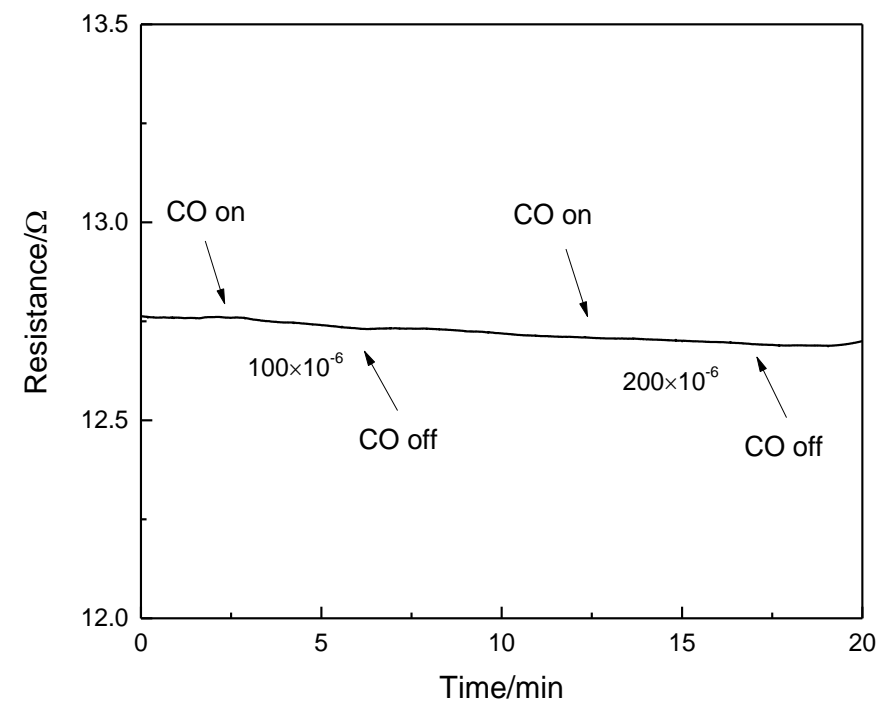

Fig.S3 Resistance change of Ni-PdO-5 material to $100 \times 10^{-6}$ and $200 \times 10^{-6}$ (volume fraction) $\mathrm{CO}$ balanced by $5 \% \mathrm{O}_{2}$ and $\mathrm{N}_{2}$ at $450{ }^{\circ} \mathrm{C}$ 